\title{
Assessment of heterogeneity of two cultivars of Olea europaea based on the study of their Ole e 1 protein content
}

\author{
Sevcan Celenk ${ }^{1}$ (D) Buse Vatansever ${ }^{1}$ \\ Received: 16 September 2020 / Accepted: 19 February 2021 / Published online: 27 February 2021 \\ (C) The Author(s), under exclusive licence to Springer-Verlag GmbH, DE part of Springer Nature 2021
}

\begin{abstract}
Olive pollen is one of the main causes of allergic disease in the Mediterranean area. Ten different proteins with allergenic activity have been described in olive pollen, with major allergen Ole e 1. Olea europaea L. may cause allergenic effects of different severity depending on the Ole e 1 content of cultivars. In this paper, we aimed to assess the heterogeneity of two olive cultivars concerning concentrations of the major allergen Ole e 1 during a period of 2 years. Pollens from two most common olive cultivars, known as "Gemlik" and "Celebi," were analyzed on regular basis. Ole e 1 amounts were measured by doublesandwich enzyme-linked immunosorbent assay (ELISA). The results were expressed as $\mu \mathrm{g}$ of Ole e 1 per $\mu \mathrm{g}$ of total freezedried extract. Comparisons of Ole e 1 levels were made both between individual trees and between cultivars. It was analyzed the influence of some meteorological parameters on pollen counts/allergenic content on a local scale, for 2 years. Pollen sampling was carried out continuously for 2 years, using a Hirst-type volumetric trap. "Gemlik" had the higher value (mean \pm standard deviation) of Ole e 1 content $(2.44 \pm 0.70$ and $1.87 \pm 1.03 \mu \mathrm{g} / \mu \mathrm{g}$, respectively) when compared to "Celebi" ( $2.16 \pm 0.86$ and 0.20 $\pm 0.30 \mu \mathrm{g} / \mu \mathrm{g}$, respectively) in the years 2013 and 2015. In our research, daily variations were observed in pollen samples of two olive cultivars and even different trees of the same cultivar. Furthermore, during certain sampling days, discrepancies between airborne pollen counts and Ole e 1 concentrations were detected for both cultivars. It was found that meteorological changes, especially temperature and precipitation fluctuations, could affect airborne pollen and Ole e 1 allergen levels in the atmosphere. Therefore, pollen samples of different $O$. europaea cultivars demonstrated great differences in Ole e 1 content. We believe that these findings were a result of alternate bearing behavior modulated by meteorological factors.
\end{abstract}

Keywords Cultivar · Olive pollen · Aeroallergens $\cdot$ Ole e $1 \cdot$ Allergen content $\cdot$ Double-sandwich ELISA

\section{Introduction}

Respiratory allergic diseases (rhinoconjunctivitis and/or bronchial asthma) caused by pollen allergens are becoming increasingly common in recent years, especially due to increased air pollution and subsequent interaction of pollen allergens with atmospheric chemical particles (Devalia et al. 1998; Fleming and Crombie 1987; Knox 1993; Turkeltaub and Gergen 1991; Wüthrich 1989). Olea

Responsible Editor: Lotfi Aleya

Sevcan Celenk

sevcancelenk@uludag.edu.tr

1 Department of Biology, Aerobiology Laboratory, Faculty of Arts and Science, Bursa Uludag University, 16059, Görükle, Nilüfer, Bursa, Turkey europaea L. (olive plant, Oleaceae family) is one of the economically important plants, broadly spreads in countries located in the Mediterranean Basin (Carnés Sánchez et al. 2002). The olive plant began to be cultured a few thousand years ago, and nowadays there are various and numerous cultivars of the plant (Zohary and Hopf 1994; Zohary and Spiegel-Roy 1975). It has been estimated that around 120 local olive cultivars exist only in Turkey alone (Efe et al. 2013) and "Gemlik" and "Celebi" cultivars selected for analysis are the most common olive cultivars in the southern Marmara region (Barut et al. 2009; Diraman 2010). More extensive cultivation of the plant is still in high demand to produce olives and olive oil in Turkey due to very favorable ecological conditions for olive farming. However, the pollens produced by $O$. europaea are responsible for seasonal allergic diseases in Mediterranean countries (D'Amato 1998; D'Amato and Liccardi 1994; Kirmaz et al. 2005), especially during May-June. 
Until today, it has been determined that there are 10 different allergens (Ole e 1-Ole e 10) in the O. europaea pollens (Barral et al. 2004; Rodríguez et al. 2002). The kind, expression levels, and allergic effects of these allergenic proteins in the pollens of olive plant show significant differences according to the origin of the cultivars (Alché et al. 2007; Castro et al. 2003). It is estimated that allergen protein differences among cultivars may be an adaptive feature that plants have developed in ecotype against different environmental conditions (Alché et al. 2007). The major allergen present in olive tree pollens, identified as Ole e 1, is a glycoprotein of $18-22 \mathrm{kDa}$ consisting of 145-amino acid polypeptide and denominates "pollen proteins of the Ole e 1 family" (Accession PF01190) within the Pfam protein families database (Batanero et al. 1994; Bateman et al. 2004; Rodríguez et al. 2002, 2007; Villalba et al. 1990). It has been suggested that the Ole e 1 allergen protein participates in important biological events such as hydration, germination, and/or pollen tube development observed during pollen formation (Alché et al. 1999, 2004; Stratford et al. 2001).

The Ole e 1 allergen leads to $\operatorname{IgE}$ (immunoglobulin E)mediated allergic response in the majority of people with allergic sensitization to olive pollen (Fernandez-Gonzalez et al. 2020, Soleimani et al. 2013). According to the origin of the olive cultivars, the IgE response to this aeroallergen varies, determining the severity of the allergic reactions (Carnés Sánchez et al. 2002; Castro et al. 2003; Conde-Hernández et al. 2002; Waisel et al. 1996). Cultivars with higher Ole e 1 content may increase allergic symptoms and/or severity of these symptoms. Ole e 1 allergen levels varying depending on the cultivar origin are clinically important. Analysis of Ole e 1 allergen levels from different varieties may contribute to the development of different allergen extracts and testing of allergic patients with these extracts. In this way, it can be aimed to decrease the sensitivity in the population (Castro et al. 2003).

A number of studies have been conducted to determine the amount of Ole e 1 allergen in total protein extracts prepared from pollens belonging to different olive cultivars. In these studies, it has been determined that the major allergen Ole e1 amount in the olive pollens shows an inter-cultivar variation (Barber et al. 1990; Carnés Sánchez et al. 2002; Castro et al. 2003; Conde-Hernández et al. 2002; Fernández-Caldas et al. 2007; Lauzurica et al. 1988a, b; Lombardero et al. 1992; Obispo et al. 1993; Villalba et al. 1990). Ole e 1 allergens, which differ in concentrations according to the cultivar origin, have been reported to cause different severity of reactivity in allergic patients through the skin prick test (Castro et al. 2003).

The widespread use of commercially available O. europaea pollen extracts, composed of a pollen mixture of unknown origin of cultivars or from different sources, in clinical and biological studies limits diagnosis and immunotherapy of allergic reactions in patients besides leading to different results at a noticeable level. Therefore, clinical use of pure Ole e 1 allergens belonging to olive cultivars in the area where the patients live and are exposed may contribute to more effective diagnoses (Alché et al. 2007; Castro et al. 2003).

This study aimed to determine Ole e 1 concentrations of two different Olea europaea cultivars, "Gemlik" and "Celebi," widely distributed in Turkey as well as to identify whether there are distinctive characteristics about Ole e 1 content between two cultivars. For this purpose, a doublesandwich enzyme-linked immunosorbent assay (ELISA) was utilized to determine in vitro Ole e 1 content of cultivars.

\section{Materials and methods}

\section{Study area}

The current study, which measured airborne $O$. europaea pollen counts and levels of Ole e 1 allergens in pollen, was conducted in Bursa $\left(41^{\circ} 11^{\prime} \mathrm{N}, 29^{\circ} 04^{\prime} \mathrm{E}\right)$ during 2013 and 2015. The city of Bursa is located in the northwest of Turkey, at a height of $106 \mathrm{~m}$ above sea level, with a transitional climate type between the Mediterranean climate and the Black Sea climate. Furthermore, the elevations of Uludağ Mountain strongly affect the climate, keeping the annual mean temperature at $14.6{ }^{\circ} \mathrm{C}$ and annual average rainfall at $707.6 \mathrm{~mm}(90$ year averages, 1928-2018, supplied by Turkish State Meteorological Service). The study was conducted in Bursa, which is an important place for olive production in Turkey.

\section{Sampling and analysis of pollen grains}

O. europaea pollen sampling was carried out continuously during 2013 and 2015, using a Hirst-type volumetric trap (Hirst 1952). The trap was placed at $40^{\circ} 22^{\prime} 33^{\prime \prime} \mathrm{N}$ and $28^{\circ}$ $86^{\prime} 42^{\prime \prime}$ E approximately $12 \mathrm{~m}$ above the ground level and 106 $\mathrm{m}$ above the sea level. Pollen grains were collected from the air continuously during May and June in 2013 and 2015, captured using a Melinex tape, which was coated with an adhesive silicone solution. The captured pollen samples were placed on glass slides coated with glycerogelatine-basic fuchsine. The pollen grains were executed under the light microscope with a magnification of $\times 40$. Sampling and data analysis were conducted by the protocol drawn up by the Spanish Aerobiology Network (REA) and the minimum recommendations of the European Aeroallergen Network (Galán et al. 2014). Pollen slides were evaluated from $12: 00 \mathrm{~h}$ to $12: 00 \mathrm{~h}$ in each sampling period, and these values were stated as daily average pollen grains per cubic meter of air (Galán et al. 2014). 


\section{Collection of pollen samples for allergen quantification}

O. europaea pollen samples were obtained during May of 2013 and May-June of 2015 from five trees selected from each of the two olive cultivars, Gemlik and Celebi. Those were collected by expert personnel trained in the identification of olive tree cultivars and the collection of pollen. The samples were collected from the flowering shoots of the selected trees and brought to the laboratory environment inside paper bags. Unknown materials were eliminated from the pollen samples using a sieve with $150 \mu \mathrm{m}$ mesh. Light microscopy was used to determine the proportion of foreign-species pollen in the obtained pollen sample. All pollen samples had a purity greater than $90 \%$. Both of the cultivars were planted in the same locations and close to each other in İznik, Bursa. All of the trees were lined south in the planting area.

\section{Preparation of crude protein extracts}

Crude protein extractions were performed following the methodology described by Carnés Sánchez et al. (2002). Briefly, crude protein extracts were obtained by stirring $6 \mathrm{~g}$ of each pollen sample in $30 \mathrm{ml}$ of phosphate-buffered saline (PBS) $0.01 \mathrm{M}(\mathrm{pH} 7.4)$ for $4 \mathrm{~h}$ at $4^{\circ} \mathrm{C}$. The sample was centrifuged at $16,266 \mathrm{~g}$ at $4^{\circ} \mathrm{C}$ for $30 \mathrm{~min}$, so that the unwanted particles were deposited on the bottom. After centrifugation, the supernatant was collected, and the pellet was resuspended in $30 \mathrm{ml}$ of PBS (0.01 M, pH 7.4), extracted overnight at $4^{\circ} \mathrm{C}$ with a constant magnetic stirring. Afterward, the extract was centrifuged at $16,266 \mathrm{~g}$, and the supernatant was collected. The whole extract was then filtered through a $0.22 \mu \mathrm{m}$ filter to sterilize the sample, frozen, lyophilized, and stored at $-80^{\circ} \mathrm{C}$ until further analysis.

\section{Ole e 1 quantification by double-sandwich enzyme- linked immunosorbent assay}

Ole e 1 allergen concentrations in the pollen extracts of two cultivars were determined by double-sandwich ELISA method, which quantify antigens between two layers of antibodies. Double-sandwich ELISA method was carried out by following the methodology performed by Arilla et al. (2002), Arilla et al. (2005), Arilla et al. (2006), Moreno-Grau et al. (2006), and Rodríguez Rajo et al. (2011). The mouse anti-Ole e 1 monoclonal antibody 5A3 (Bial Industrial Pharmaceutical, Spain at $0.55 \mathrm{mg} / \mathrm{ml}$ ) was diluted in coating buffer, containing $\mathrm{Na}_{2} \mathrm{CO}_{3}$, $\mathrm{NaHCO}_{3}$, and distilled $\mathrm{H}_{2} \mathrm{O}$, at a concentration of 5 $\mu \mathrm{g} / \mathrm{ml}$. Afterward, 96-well microplate (Greiner Bio-One, Germany) was coated with $100 \mu \mathrm{l}$ of corresponding monoclonal antibody $5 \mathrm{~A} 3$, and this mixture was incubated overnight at $+4^{\circ} \mathrm{C}$ to allow complete binding. The next day, the plate was emptied and all of wells were washed three times with $200 \mu 1$ PBS-T buffer (PBS + 0.05\% Tween 20). After the washing step, the plate was blocked with $200 \mu \mathrm{l} /$ well of PBS-T-B (PBS $+0.05 \%$ Tween 20 and $1 \%$ bovine serum albumin, BSA; Sigma-Aldrich, USA) and incubated for $1 \mathrm{~h}$ at $37^{\circ} \mathrm{C}$ to block any non-specific binding sites on the plate surface. Afterward, a $100 \mu \mathrm{l} /$ well of the standard curve (Bial Industrial Pharmaceutical, Spain at $2.5 \mu \mathrm{g} / \mathrm{ml}$ ), 10 $\mathrm{ng} / \mathrm{ml}$ positive control $\mathrm{A}$, and $1 \mathrm{ng} / \mathrm{ml}$ positive control B (Bial Industrial Pharmaceutical, Spain) solutions, together with antigen-containing sample extracts, diluted with PBST-B buffer according to daily pollen amounts, were added and incubated for $1 \mathrm{~h}$ at $37{ }^{\circ} \mathrm{C}$. After 1-h incubation, the plate was washed three times with $200 \mu \mathrm{l}$ PBS-T buffer, in order to remove the unbound antigen. The $100 \mu \mathrm{l} / \mathrm{well}$ of biotinylated rabbit anti-Ole e 1 polyclonal antibody (Bial Industrial Pharmaceutical, Spain at $0.65 \mathrm{mg} / \mathrm{ml}$ ) was diluted in PBS at a concentration of $0.25 \mu \mathrm{g} / \mathrm{ml}$, added to the plate wells, and incubated for $1 \mathrm{~h}$ at $37^{\circ} \mathrm{C}$. The plate was then washed with $200 \mu \mathrm{l}$ PBS-T buffer, followed by 100 $\mu \mathrm{l} /$ well of peroxidase-conjugated streptavidin (SigmaAldrich, USA) and $250 \mathrm{ng} / \mathrm{ml}$ concentration of PBS-T-B buffer, which was then applied to the plate wells and incubated for $1 \mathrm{~h}$ at $37^{\circ} \mathrm{C}$. Lastly, the sample was washed three times with $200 \mu \mathrm{l}$ PBS-T buffer to remove the unbound antibody-enzyme conjugates, and the plate wells were incubated for $10 \mathrm{~min}$ with $100 \mu \mathrm{TMB}\left(3,3^{\prime}, 5,5^{\prime}\right.$ tetramethylbenzidine; Sigma-Aldrich, USA) solution. This reaction was stopped by adding $100 \mu \mathrm{l} /$ well of $3 \mathrm{M}$ $\mathrm{H}_{2} \mathrm{SO}_{4}$ stop solution. Absorbance was measured with a microplate reader (ELx808, BioTek, USA) at $450 \mathrm{~nm}$.

The standard curve was drawn from a sequential dilution $(0.10$ to $50 \mathrm{ng} / \mathrm{ml})$ of purified standard allergens Ole e 1 at concentrations of 0.97 to $50 \mathrm{ng} / \mathrm{ml}$ distributed regularly throughout the columns of the microplates. The standards and samples were analyzed as duplicates. The final standard curve was represented by the average of the two absorbance values, in order to minimize potential error. The results expressed in $\mu \mathrm{g}$ of Ole e 1 per $\mu \mathrm{g}$ of total freeze-dried extract.

\section{Weather data}

In order to determine the relationship of airborne $O$. europaea pollen and Ole e 1 allergen content with weather conditions, the meteorological analysis was performed during the period of sampling of pollen and allergens. The meteorological parameters used in the analysis were maximum, minimum, and average daily temperature $\left({ }^{\circ} \mathrm{C}\right)$; relative humidity $(\%)$; and total precipitation amount $(\mathrm{mm})$ with the maximum and the average daily wind speed $(\mathrm{m} / \mathrm{s})$. This data was provided by the Turkish State Meteorological Service at a weather station located near the studying area. 


\section{Statistical analysis}

Pollen and allergen concentrations on the sampling days were compared with the daily meteorological data on the same days. Spearman's rank correlation test was performed for data analysis. Statistical analysis was performed using the SPSS version 23 software package for Windows.

\section{Results}

\section{Pollen concentration}

O. europaea flowering continued during May and June in Bursa, Turkey. Pollen analysis of $O$. europaea during the flowering period May-June showed significant differences in pollen index and pollen season length between 2013 and 2015. In 2013, the length of the pollen season was 44 days, and it covered the period from May 15 to June 27. The total number of pollen sampled for this period was 1500 grains $/ \mathrm{m}^{3}$, and daily pollen peak was recorded on May 21 with 401 pollen $/ \mathrm{m}^{3}$. The length of the pollen season in 2015 was shorter than 2013, covering the 36-day period from May 15 to June 19. Unlike 2013, a remarkable increase in total number of pollen grains was determined in 2015, reaching 6186 grains $/ \mathrm{m}^{3}$ for this period. The maximum daily pollen peak was $1717 \mathrm{pollen} / \mathrm{m}^{3}$ on June 02 (Table 1).

\section{Differences in Ole e 1 allergen concentrations of Olea europaea cultivars}

Ole e 1 concentrations were compared in pollen samples of Gemlik and Celebi cultivars, which are two different O. europaea cultivars. Pollen samples were collected from five trees, which were selected from each of the two olive cultivars. Pollen sampling days are May 21, 23, and 25, 2013, and May 27, 30, and 31 and June 01, 02, and 05, 2015.

Allergen-specific double-sandwich ELISA method was used to measure Ole e 1 concentrations of a certain amount of pollen grains. The results expressed in $\mu \mathrm{g}$ of Ole e 1 per $\mu \mathrm{g}$ of total freeze-dried extract. Ole e 1 concentrations in pollen samples collected from a total of ten olive trees for the two

Table 1 Characteristics of the Olea sp. pollen seasons in 2013 and 2015

\begin{tabular}{lll}
\hline Olea europaea pollen & 2013 & 2015 \\
\hline Peak value (pollen/m³ & 401 & 1717 \\
Peak day & 21 May & 02 June \\
Pollen index (total pollen/season) & 1500 & 6186 \\
Pollen season (date) & $15 / 05$ to 27/06 & $15 / 05$ to $19 / 06$ \\
Season length (days) & 44 & 36 \\
\hline
\end{tabular}

olive cultivars according to the sampling dates are shown in Fig. 1.

According to the double-sandwich ELISA data, on May 21, 2013, there were similar values between the Gemlik and Celebi cultivars in terms of Ole e 1 concentration. However, Ole e 1 contents of Gemlik $3(0.04 \mu \mathrm{g} / \mu \mathrm{g})$ and Celebi $3(0.56 \mu \mathrm{g} / \mu \mathrm{g})$ cultivars was quite low. On May 23, 2013, Ole e 1 concentrations differed among samples of Celebi cultivars, although they were similar between samples from Gemlik cultivars. Ole e 1 concentration of Celebi 4 ( 0.83 $\mu \mathrm{g} / \mu \mathrm{g}$ ) cultivar was lower than from other samples of the Celebi cultivar. On May 25, 2013, sampling day, the Ole e 1 allergen was detected only for Gemlik 1, Celebi 1, and Celebi 3 cultivars. However, the concentration of Ole e 1 in the Celebi 3 sample $(0.05 \mu \mathrm{g} / \mu \mathrm{g})$ was significantly lower compared to Gemlik 1 and Celebi $1(1.41 \mu \mathrm{g} / \mu \mathrm{g}$ and $1.42 \mu \mathrm{g} / \mu \mathrm{g}$, respectively). Interestingly, on May 27, 2015, Ole e 1 allergens were detected only in pollen samples of Celebi 1 (2.79 $\mu \mathrm{g} / \mu \mathrm{g}$ ) among all cultivars. On May 30, 2015, Ole e 1 concentrations of all Gemlik cultivars except Gemlik $4(0.75 \mu \mathrm{g} /$ $\mu \mathrm{g})$ were high and close to each other. However, only Celebi 1 $(1.24 \mu \mathrm{g} / \mu \mathrm{g})$ was calculated for Ole e 1 among the Celebi samples at this date. On May 31, 2015, it was seen that the Ole e 1 allergen level of Gemlik $4(0.14 \mu \mathrm{g} / \mu \mathrm{g})$ was very low compared to other Gemlik samples. On this date, the Ole e 1 allergen level was very low in the samples of the Celebi cultivar. On June 1, 2015, Ole e 1 allergen was detected in the samples Gemlik $2(3.38 \mu \mathrm{g} / \mu \mathrm{g})$, Gemlik $3(2.60 \mu \mathrm{g} / \mu \mathrm{g})$, and Gemlik $5(1.41 \mu \mathrm{g} / \mu \mathrm{g})$ for the Gemlik cultivars, and in the Celebi 1 sample $(1.52 \mu \mathrm{g} / \mu \mathrm{g})$ alone for the Celebi cultivars. The Ole e 1 allergen concentrations in Gemlik $3(0.88 \mu \mathrm{g} / \mu \mathrm{g})$ and Gemlik $4(0.59 \mu \mathrm{g} / \mu \mathrm{g})$ samples on June 2, 2015, were much lower compared to other samples. On the same date, the concentrations of Ole e 1 allergens in Celebi cultivars, compared to Gemlik cultivars, were quite poor. On June 4, 2015, no allergen was determined in samples of both Gemlik and Celebi cultivars, whereas on June 5, 2015, Ole e 1 allergen was measured for only Celebi 1 sample $(1.24 \mu \mathrm{g} / \mu \mathrm{g})$ (Fig. 1).

The average of Ole e 1 concentrations on the sampling days of Gemlik and Celebi cultivars was given in Table 2 for both years. According to double-sandwich ELISA results, the average Ole e 1 contents of Gemlik and Celebi cultivars represented considerable differences between 2013 and 2015. Ole e 1 concentrations of both Gemlik and Celebi cultivars were lower in 2015 compared to 2013 data. In particular, the decrease in Ole e 1 content of Celebi cultivars was noteworthy. In 2013, the Ole e 1 content of the Gemlik cultivar (mean \pm standard deviation; $2.44 \pm 0.70 \mu \mathrm{g} / \mu \mathrm{g}$ ) was found to be higher than that of the Celebi cultivar (mean \pm standard deviation; $2.16 \pm 0.86 \mu \mathrm{g} / \mu \mathrm{g})$. Similar results were also obtained in 2015 . In 2015, Ole e 1 amount of Gemlik cultivar was measured as $1.87 \pm 1.03 \mu \mathrm{g} / \mu \mathrm{g}$ (mean \pm standard deviation), while Ole e 1 of Celebi cultivar was determined as $0.20 \pm 0.30 \mu \mathrm{g} / \mu \mathrm{g}$ (mean 
Fig. 1 Ole e 1 contents of both Gemlik and Celebi cultivars according to the pollen sampling dates

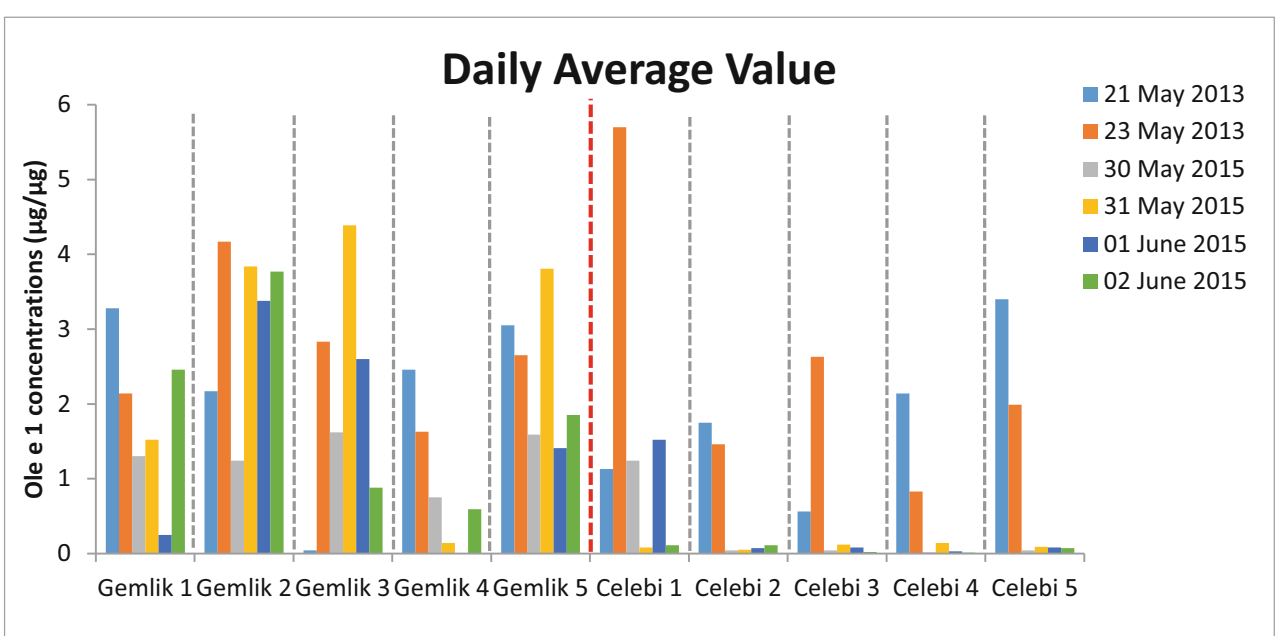

\pm standard deviation). During the studying period, Ole e 1 content was highest in the Gemlik 2. On the other hand, the yearly average Ole e 1 contents were lowest in Gemlik 4. Among Celebi cultivars, Ole e 1 concentration was the highest in Celebi 1, while the cultivar with the lowest Ole e 1 concentration was Celebi 4 on a yearly average. In summary, the amount of Ole e 1 of Gemlik cultivars was higher than in Celebi cultivars in both years (Table 2).

\section{Relationship between pollen counts and Ole e 1 allergen concentrations of Olea europaea cultivars}

In this study, variations in both $O$. europaea pollen amounts and Ole e 1 allergen concentrations by years and days were investigated. Discordance between pollen counts and Ole e 1 allergen concentrations were recorded at different sampling

Table 2 Average Ole e 1 concentrations of the Gemlik and Celebi cultivars of $O$. europaea according to years

\begin{tabular}{lcc}
\hline Olea europaea Cv. & \multicolumn{2}{c}{ The average of Ole e 1 concentrations* } \\
\cline { 2 - 3 } & 2013 year & 2015 year \\
\hline Gemlik 1 & $2.71 \pm 0.81$ & $1.38 \pm 0.91$ \\
Gemlik 2 & $3.17 \pm 1.41$ & $3.06 \pm 1.23$ \\
Gemlik 3 & $1.44 \pm 1.97$ & $2.37 \pm 1.52$ \\
Gemlik 4 & $2.05 \pm 0.59$ & $0.37 \pm 0.36$ \\
Gemlik 5 & $2.85 \pm 0.28$ & $2.17 \pm 1.11$ \\
Average of Gemlik cultivars & $2.44 \pm 0.70$ & $1.87 \pm 1.03$ \\
Celebi 1 & $3.42 \pm 3.23$ & $0.74 \pm 0.75$ \\
Celebi 2 & $1.61 \pm 0.21$ & $0.07 \pm 0.03$ \\
Celebi 3 & $1.60 \pm 1.46$ & $0.07 \pm 0.04$ \\
Celebi 4 & $1.49 \pm 0.93$ & $0.05 \pm 0.06$ \\
Celebi 5 & $2.70 \pm 1.00$ & $0.07 \pm 0.02$ \\
Average of Celebi cultivars & $2.16 \pm 0.86$ & $0.20 \pm 0.30$ \\
\hline
\end{tabular}

*Ole e $1 \mu \mathrm{g} / \mu \mathrm{g}$ total freeze-dried extract periods of Gemlik and Celebi cultivars (Fig. 2). In sampling days of 2013, there was an inverse relationship between total pollen values and Ole e 1 concentrations for Gemlik and Celebi cultivars. For these cultivars, both low pollen amounts and high allergen concentrations were detected on May 23, 2013. On May 21 and 25, 2013, there was a positive relationship between the total pollen values and Ole e 1 concentrations of Gemlik and Celebi cultivars. On May 21, 2013, both high pollen concentration and high Ole e 1 content were detected, while on May 25, 2013, both of these values were low (Fig. 2a and c). The negative relationship in Gemlik cultivars was also available in 2015 year. Although the pollen counts in the atmosphere were negligible on May 30, 2015, the presence of allergen was observed in the pollen samples belonging to Gemlik cultivar. The most striking result for the Gemlik cultivar was obtained on May 31, 2015. Although the atmospheric pollen amount was very low at this date, the highest Ole e 1 concentration was detected (Fig. 2b). In 2015 year, daily variations between pollen and allergen amounts were also recorded in Celebi cultivars. On May 27 and June 02, 2015, the discrepancy between the allergen concentrations and the amount of pollen in this cultivar was remarkable. On May 27, 2015, although the airborne pollen amount was low, the highest concentration of Ole e 1 allergen was reached in pollen samples. Similar results were found on May 30, 2015. On the other hand, quite the opposite was observed on June 02, 2015, where a high atmospheric pollen level and low Ole e 1 concentration was detected for Celebi cultivars (Fig. 2d).

\section{Relationship between meteorological parameters, pollen, and Ole e 1 allergen contents of Olea europaea cultivars}

To investigate the relationship $O$. europaea pollen counts and Ole e 1 concentrations with atmospheric changes, weather data analysis was performed simultaneously with pollen 
Fig. 2 Relationship between O. europaea pollen amounts and Ole e 1 allergen concentrations for Gemlik $(\mathbf{a}, \mathbf{b})$ and Celebi cultivars $(\mathbf{c}, \mathbf{d})$ in the years 2013 and 2015
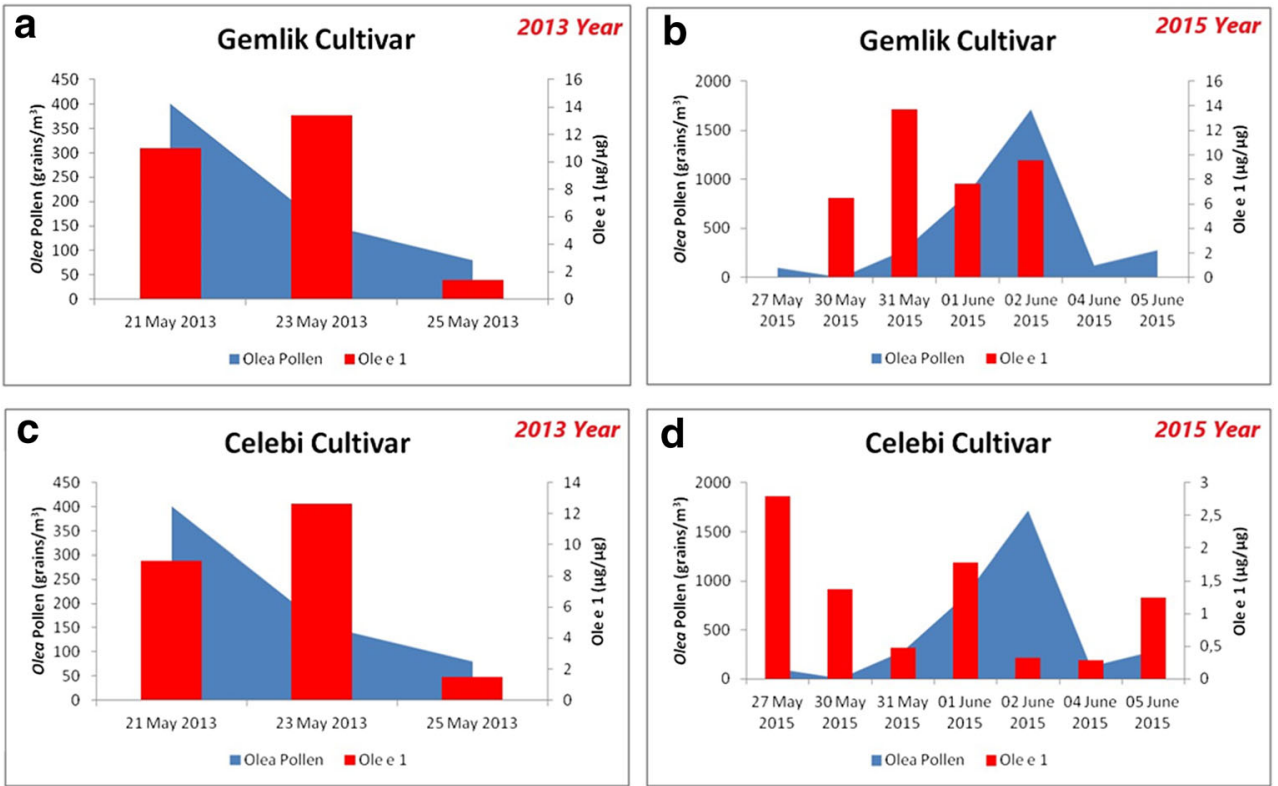

counts and double-sandwich ELISA test. The values of meteorological parameters, such as maximum, minimum, and average daily temperature $\left({ }^{\circ} \mathrm{C}\right)$; relative humidity $(\%)$; and total precipitation amount $(\mathrm{mm})$ together with maximum and average wind speed (m/s), are given in Table 3. In 2013 and 2015, meteorological data were similar, except for relative humidity and total precipitation. The year 2013 was a more rainy year than 2015, with a total rainfall of $1267 \mathrm{~mm}$. On the other hand, 2015 was a more humid year than the other year with a relative humidity of $73.7 \%$. The pollen season of the year 2013 was less intense corresponding with lower humidity and a higher total rainfall value. In contrast, the pollen season of 2015 was more intense, corresponding to higher humidity and lower total rainfall.

Table 3 Meteorological data on the study area in 2013 and 2015

\begin{tabular}{|c|c|c|c|c|c|c|c|}
\hline & $\begin{array}{l}\text { Average } \\
\text { temperature }\left({ }^{\circ} \mathrm{C}\right)\end{array}$ & $\begin{array}{l}\text { Maximum } \\
\text { temperature }\left({ }^{\circ} \mathrm{C}\right)\end{array}$ & $\begin{array}{l}\text { Minimum } \\
\text { temperature }\left({ }^{\circ} \mathrm{C}\right)\end{array}$ & $\begin{array}{l}\text { Relative } \\
\text { humidity }(\%)\end{array}$ & $\begin{array}{l}\text { Total } \\
\text { precipitation } \\
(\mathrm{mm})\end{array}$ & $\begin{array}{l}\text { Average wind } \\
\text { speed }(\mathrm{m} / \mathrm{s})\end{array}$ & $\begin{array}{l}\text { Maximum wind } \\
\text { speed }(\mathrm{m} / \mathrm{s})\end{array}$ \\
\hline $\begin{array}{l}2013 \\
\quad \text { (mean) }\end{array}$ & 15.3 & 21.1 & 10.0 & 66.3 & 1267.0 & 2.3 & 8.9 \\
\hline $\begin{array}{l}\text { Pollen } \\
\text { season }\end{array}$ & 22.2 & 28.8 & 15.5 & 58.6 & 78.4 & 2.5 & 9.7 \\
\hline \multicolumn{8}{|c|}{ Sampling days } \\
\hline 21 May & 21.9 & 30.3 & 13.7 & 58.3 & 0.0 & 1.5 & 6.2 \\
\hline 23 May & 26.3 & 35.4 & 18.1 & 44.9 & 0.0 & 3.9 & 17.5 \\
\hline 25 May & 22.7 & 28.6 & 14.6 & 44.0 & 0.0 & 3.2 & 9.3 \\
\hline $\begin{array}{l}2015 \\
\text { (mean) }\end{array}$ & 15.4 & 21.0 & 10.3 & 73.7 & 660.9 & 2.4 & 8.7 \\
\hline $\begin{array}{l}\text { Pollen } \\
\text { season }\end{array}$ & 20.9 & 26.5 & 16.7 & 73.2 & 64.2 & 2.1 & 7.9 \\
\hline \multicolumn{8}{|c|}{ Sampling days } \\
\hline 27 May & 19.4 & 21.7 & 15.8 & 75.3 & 0.0 & 1.3 & 6.7 \\
\hline 30 May & 16.7 & 21.3 & 12.1 & 68.9 & 0.0 & 2.0 & 6.2 \\
\hline 31 May & 17.9 & 24.6 & 10.3 & 69.0 & 0.0 & 1.8 & 8.2 \\
\hline 01 June & 19.5 & 26.3 & 11.7 & 68.4 & 0.0 & 2.3 & 9.3 \\
\hline 02 June & 20.8 & 27.8 & 13.5 & 69.0 & 0.0 & 2.9 & 11.8 \\
\hline 04 June & 20.5 & 26.1 & 16.5 & 78.1 & 8.2 & 2.2 & 7.7 \\
\hline 05 June & 19.2 & 22.7 & 14.9 & 83.0 & 0.0 & 1.1 & 6.2 \\
\hline
\end{tabular}

The maximum-minimum temperature $\left({ }^{\circ} \mathrm{C}\right)$ and the maximum wind speed $(\mathrm{m} / \mathrm{s})$ values in 2013 and 2015 were expressed as average value 
During the study period, although the annual mean average, annual mean maximum, and annual mean minimum temperature values were similar, it was determined that the daily temperature values were higher, especially on the sampling days of 2013 (Table 3). On the sampling days of 2013, when the temperature values were high, low pollen numbers and high Ole e 1 concentrations were obtained, while on the sampling days of 2015 when the temperature values were low, the opposite results were recorded (Figs. 3a and 4a). In addition, low pollen concentrations were found in the atmosphere during the sampling days in 2013 when the humidity levels were low. For the year 2015, the average relative humidity was higher, and the total number of pollen was also higher (Fig.3b). These results showed that relative humidity can have a significant effect on the concentrations of $O$. europaea pollens. In contrast, it was observed that relative humidity did not have a remarkable effect on Ole e 1 concentrations (Fig. 4b). The pollen season for $O$. europaea in 2013 was slightly more rainy than in 2015 , even though the weather was dry and rainfree during the days when the pollen was exemplified. Furthermore, short-term rains were observed before the pollen sampling dates in 2013. These data showed that the total rainfall rates for both years may have increased the average Ole e 1 concentrations of Gemlik and Celebi cultivars (Fig. 4c).

\section{Discussion}

Olea europaea L. (olive tree, Oleaceae family) is an allergic pollen-producing plant in Mediterranean countries and is the most important cause of seasonal allergic respiratory diseases (D'Amato et al. 2007a; Ribeiro et al. 2013). In most of these countries, many olive tree varieties/cultivars are cultivated for their fruits commercially and as ornamental plants in parks and gardens (D'Amato et al. 2007a; Fernández-Caldas et al. 2007; Machia et al. 1991). O. europaea is a natural plant species in Turkey. It is also frequently cultured because of its economic importance. In particular, O. europaea trees are intensely spread in Western Turkey, including the city of Bursa, where the effects of a transitional climate type between the Mediterranean climate and the Black Sea climate can be observed. Therefore, O. europaea pollen, which triggers allergic symptoms, is highly detected in the air of this region (Akkaya et al. 2018).

Investigating and detecting the concentrations of proteins involved in pollen development is of great importance in determining the degree of allergic effect. The variations of Ole e 1 concentrations, the main allergen in olive pollen, between cultivar species were stated in previous studies (Lauzurica et al. 1988a; Lombardero et al. 1992; Villalba et al. 1993). Many authors reported that the allergen proteins in olive pollen can be polymorphic according to the origin of the cultivars and that the allergenic content of these proteins can vary between cultivars (Alché et al. 2007; Castro 2001; Castro et al. 2003; Carnés Sánchez et al. 2002; Conde-Hernández et al. 2002; Fernández-Caldas et al. 2007; Geller-Bernstein et al. 1996; Hamman-Khalifa 2005; Hamman-Khalifa et al. 2003; Napoli et al. 2006; Waisel and Geller-Bernstein 1996). Therefore, identifying the allergic potentials of olive cultivars can be clinically valuable.
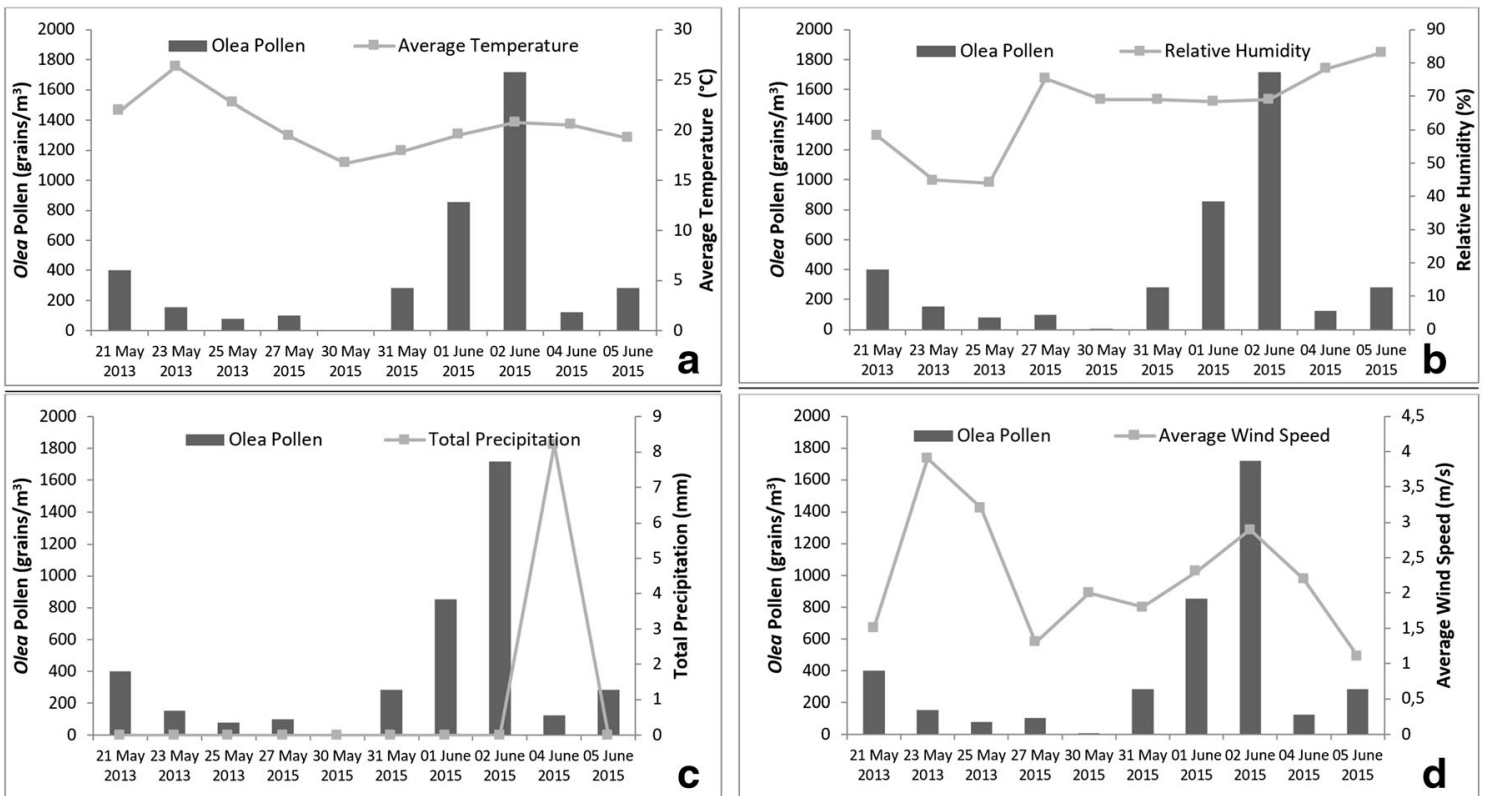

Fig. 3 Relationship between meteorological parameters; average temperature (a), relative humidity (b), and total precipitation (c) together with average wind speed (d) and pollen amounts for Gemlik and Celebi cultivars on the sampling days 

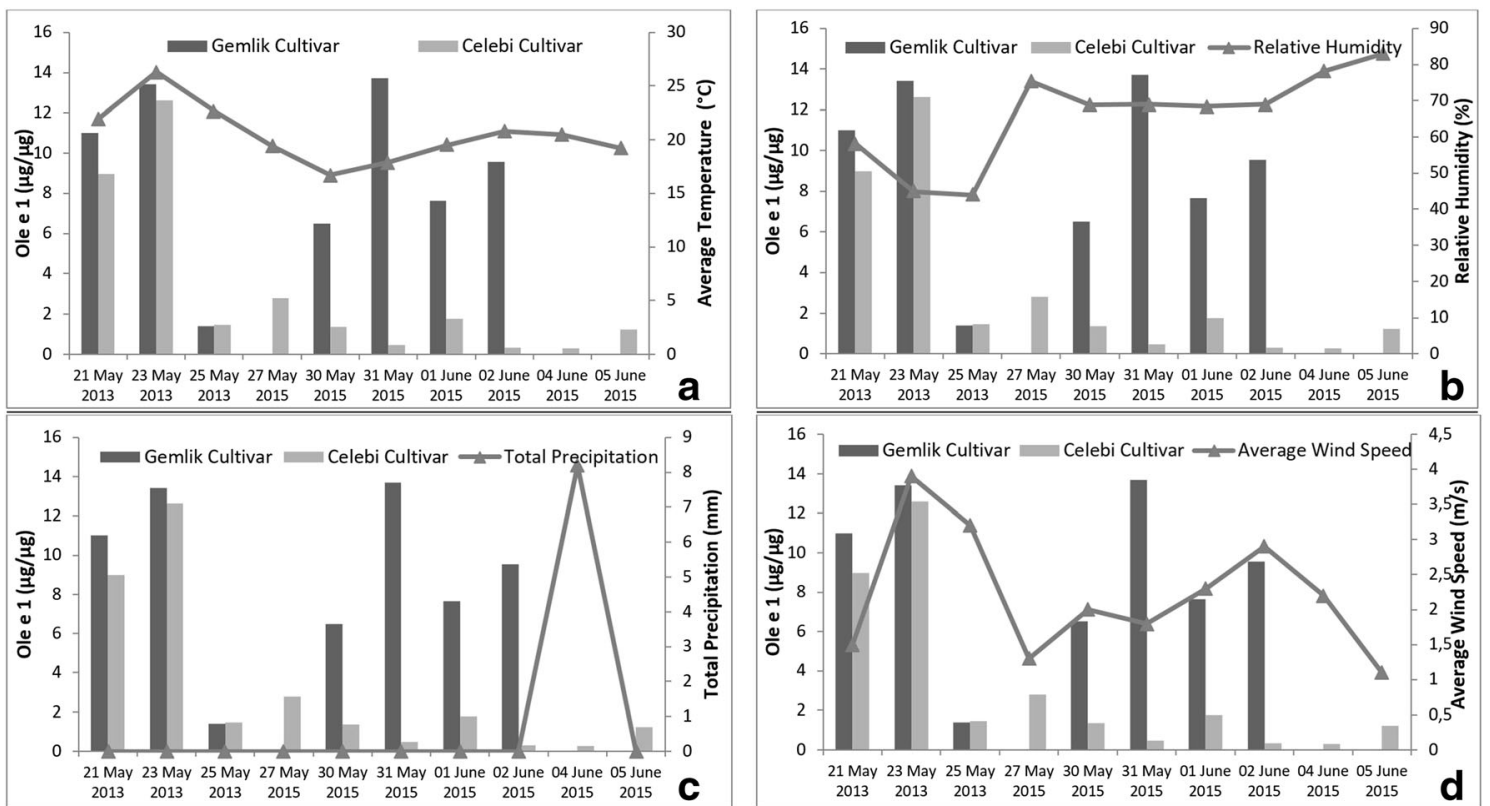

Fig. 4 Relationship between meteorological parameters; average temperature (a), relative humidity (b), and total precipitation (c) together with average wind speed (d) and Ole e 1 allergen concentrations for Gemlik and Celebi cultivars on the sampling days

The present study aimed to determine whether the Ole e 1 concentrations of two different $O$. europaea cultivars, called "Gemlik" and "Celebi," differ from each other. Also, the relationship between the concentrations of $O$. europaea pollen and the allergen concentrations of the two cultivars in the air was also analyzed during the study period. In addition, the weather conditions were evaluated to understand whether these two cultivars had any effect on allergen productions.

In our study, the aerobiological monitoring of olive pollen showed that during the pollen season, high pollen levels were determined for both years. However, the number of olive pollen in 2015 was on average 4 times higher than in 2013. For a plant species, the atmospheric pollen concentrations may vary from year to year in the same region. The olive pollen profile in the air may change due to meteorological factors (D'Amato et al. 2007a).

In order to determine the Ole e 1 concentrations in 2013 and 2015 pollen samples of Gemlik and Celebi cultivars, a double-sandwich ELISA test was conducted in vitro. The results indicated that there were major differences in the Ole e 1 allergen concentrations of pollens collected from two different olive cultivars. It was noticeable that the Ole e 1 content of Gemlik cultivars was higher than the Celebi cultivars in both years. Based on this data, it can be said that Celebi cultivars are less allergenic than Gemlik cultivars. In the literature, there are several studies that support our results (Carnés Sánchez et al. 2002; Fernández-Caldas et al. 2007; Jaradat et al. 2012). It has been confirmed previously that such differences between varieties are observed due to genetic alterations and climatic factors (Fernández-Caldas et al. 2007). In this study, it was surprising that the pollen samples obtained from different trees of the same cultivar were found to have variations in the content of Ole e 1 . This result can be explained by the fact that pollen samples exhibit batch to batch variability in terms of allergen compositions, according to Alche et al. (2007) and Carnés Sánchez et al. (2002). Furthermore, the presence of Ole e 1 protein in several tree samples of both cultivars was never detected. This can be attributed to changing environmental conditions (Jaradat et al. 2012).

In our study, daily and yearly variations were recorded in both pollen counts and Ole e 1 allergen concentrations. During the study period, discrepancies between airborne pollen amounts and allergen levels were detected on certain sampling days. Several studies reported a high amount of pollen and low allergen content or vice versa (Buters et al. 2012; Galán et al. 2013; Moreno-Grau et al. 2016; Plaza et al. 2016). As stated in previous studies (Galan et al. 2013; Vara et al. 2016a, 2016b), the amount of olive pollen in the atmosphere is not an indication of the degree of exposure to its primary allergen Ole e 1. In this study, although pollen counts were very low on certain sampling days, Ole e 1 allergen concentrations were found to be quite high. Moreover, not only pollen grains but also other plant parts such as leaves, roots, and orbicles contain these allergen proteins, which can increase the allergen load in the air (Brito et al. 2011; Knox 1993). However, in this study, only the flowering shoots of the plant Ole e 1 quantification was performed. In our study, high Ole el concentrations may be due to an adaptation to increase Ole e 1 allergen synthesis in days and/or years when the plant produces low pollen, to ensure the chance of fertilization. The Ole e1, 
containing the major allergen protein of olive pollen, plays an important role in pollen tube germination (Alché et al. 2004; Moreno-Grau et al. 2016). Obtaining low Ole e 1 allergen concentrations on some sampling days with high pollen values was recorded as the opposite of previous data in this study. Moreover, this outcome was more notable in Celebi cultivars than in Gemlik cultivars. O. europaea varieties showing differences in Ole e 1 allergen protein production have been previously reported in the literature (FernándezCaldas et al. 2007). It has been reported in a prior study that detection of high pollen levels did not always cause an increase in allergen concentrations (Plaza et al. 2016). Largescale pollen transport from external sources may also be responsible for recording high amounts of pollen (Moreno-Grau et al. 2016). This negative relationship between daily and/or annual pollen and allergen levels may also be caused by changes in environmental/weather conditions (Moreno-Grau et al. 2016). In addition, as reported by Fernández-González et al. (2020), Moreno-Grau et al. (2016), and Erel et al. (2013), an alternate bearing behavior pattern may develop in $O$. europaea trees, characterized by a change in pollen concentration/allergen level relationship from year to year. Therefore, when comparing atmospheric pollen counts and Ole e 1 allergen contents, all variables should be considered and evaluated as a whole.

Many changes in weather conditions can affect the production of pollen and aeroallergens in the atmosphere. During the study period, a meteorological analysis was carried out on based on parameters such as maximum/minimum and average daily temperature $\left({ }^{\circ} \mathrm{C}\right)$, relative humidity $(\%)$, and total precipitation $(\mathrm{mm})$ together with maximum and average wind speed $(\mathrm{m} / \mathrm{s})$, in order to reveal the relationship between air changes and the concentrations of airborne pollen/allergens. In this study, since pollen sampling was done directly from selected trees instead of the atmosphere, it was determined that meteorological changes had an effect on the behavior model of olive trees and, consequently, on the pollen numbers and Ole e 1 allergen content of the cultivars. In our study, it was determined that the pollen counts were low and the Ole e 1 allergen concentrations were high in the 2013 pollen season when the temperature values were high. An opposite result was recorded in 2015. Due to the low temperature values in the sample days of 2015, a significant decrease in Ole e 1 concentrations of Gemlik and especially Celebi cultivars was determined. Our analysis results showed that the temperature can have an effect on Ole e 1 allergen concentrations than the number of pollen grains in the air. Several studies have reported that allergens are sensitive to temperature and are affected by temperature changes (Brito et al. 2011; Galán et al. 2013). According to the data obtained from this study, it was concluded that a more comprehensive and long-term study is required to evaluate the effect of temperature on Ole e 1 allergen concentration. Many studies have reported that atmospheric moisture induces osmatic rupture in pollen grains, causing the release of aeroallergens, thereby increasing the concentration of aeroallergens in the atmosphere (Buters et al. 2012, 2015; Fernández-González et al. 2010; Singer et al. 2005; Solomon et al. 1983; Suárez-Cervera and Seoane-Camba 2005; Suárez-Cervera et al. 2008). However, in this study, it was found that relative humidity did not have such effect on Ole e 1 concentrations. Here, relative humidity does not have a significant effect on the Ole e 1 allergen, probably due to climatic reasons, as Plaza et al. (2016) reported. The release of Ole e 1 allergens from pollen grains into the air maybe triggered by different parameters other than moisture. Other meteorological factors that determine the distribution and intensity of allergens in the atmosphere are wind intensity and precipitation. Especially, short-term precipitation before the sampling period for 2013 was followed by an increase in Ole e 1 allergen content. It is reported that pollen grains that come into contact with water after short periods of precipitation accumulate allergenic proteins on the surface and release them into the atmosphere when dry (Moreno-Grau et al. 2006). Many studies have suggested that precipitation can affect aeroallergen distributions (D'Amato et al. 2007b; Fernández-González et al. 2011; Grote et al. 2003; Knox 1993). In our research, the phenomena mentioned in these studies might have been experienced and might have caused the current result. In addition, the decrease in airborne pollen level in 2013, which was the year of abundant rainfall was observed in our research, may be due to the removal of pollen from the air by precipitation (Peternel et al. 2004).

Overall, the relationship between weather conditions and atmospheric pollen/allergen concentrations is complex and difficult to analyze. Atmospheric pollen amount and the amount of pollen grains of a plant are directly related to plant phenology (Plaza et al. 2016). Therefore, investigating the effect of weather changes on flowering phenology may provide more accurate results.

\section{Conclusions}

In this study, we aimed to compare the allergenic effects of two different cultivars of Olea europaea L. in Bursa, Turkey, according to Ole e 1 protein concentrations. Our analysis results demonstrated that Ole e 1 concentration of Gemlik cultivar was higher than that of Celebi cultivar. Based on this data, it can be said that the Gemlik cultivar is more allergenic than the Celebi cultivar. However, large-scale and long-term advanced investigations supported by clinical studies are required to confirm this data. Therefore, in order to provide more accurate and reliable data to allergy sufferers, it is important to consider pollen and allergen quantifications altogether with pollen symptoms data. 
In summary, amount of allergens released into the atmosphere may vary in the olive pollen from different cultivars. Therefore, we think that cultivar origins should be taken into consideration when evaluating allergy risk for olive pollen. Finally, in the light of our findings, we recommend that Celebi cultivars be preferred over Gemlik cultivars for olive tree planting in densely populated areas. Thus, we believe that more valuable information can be obtained to help people who are sensitive to $O$. europaea pollen.

Acknowledgements The authors would like to thank Prof. Dr. Hulusi MALYER who passed away on November 10,2020 due to a heart attack during the treatment of COVID-19 for the assistance of field studies and all of the persons who provide technical support to this study.

Availability of data and materials All data generated or analyzed during this study are included in this published article (and its supplementary information files).

Author contribution Sevcan Celenk designed the study and collected the pollen samples. Sevcan Celenk and Buse Vatansever performed the laboratory experiments, analyzed the data, and did the statistical analysis. All authors wrote and read the manuscript and approved the final manuscript.

Funding This study was funded by the Scientific Research Unit of Bursa Uludag University (project number UAP(F) 2011/76 and KUAP(F) 2016/22).

\section{Declarations}

Ethics approval and consent to participate Not applicable

Consent for publication Not applicable

Competing interests The authors declare no competing interests.

\section{References}

Akkaya M, Celenk S, Canıtez Y, Çekiç Ş, Malyer H, Sapan N (2018) Bursa atmosferindeki bazı allerjik polenler ile allerjik duyarlanma ilişkisinin araştırılması. XXV. Ulusal Allerji \& Klinik İmmunoloji Kongresi, Oral presentation, 17-21 November, Antalya-Turkey

Alché JD, Castro AJ, Olmedilla A, Fernández MC, Rodríguez R, Villalba M, Rodríguez-García MI (1999) The major olive pollen allergen (Ole e I) shows both gametophytic and sporophytic expression during anther development, and its synthesis and storage takes place in the RER. J Cell Sci 112(Pt 15):2501-2509

Alché JD, M'rani-Alaoui M, Castro AJ, Rodríguez-García MI (2004) Ole e 1, the major allergen from olive (Olea europaea L.) pollen, increases its expression and is released to the culture medium during in vitro germination. Plant Cell Physiol 45(9):1149-1157

Alché JD, Castro AJ, Jiménez-López JC, Morales S, Zafra A, HammanKhalifa AM, Rodríguez-García MI (2007) Differential characteristics of olive pollen from different cultivars: biological and clinical implications. J Investig Allergol Clin Immunol 17(Suppl 1):17-23

Arilla MC, Eraso E, Ibarrola I, Algorta J, Martínez A, Asturias JA (2002) Monoclonal antibody-based method for measuring olive pollen major allergen Ole e1. Ann Allergy Asthma Immunol 89(1):83-89
Arilla MC, Ibarrola I, Mir A, Monteseirín J, Conde J, Martínez A, Asturias JA (2005) Development of a sandwich-type ELISA for measuring Pla a 1, the major allergen of Platanus acerifolia pollen. Int Arch of Allergy Inmunol 138(2):127-133

Arilla MC, González-Rioja R, Ibarrola I, Mir A, Monteseirín J, Conde J, Martínez A, Asturias JA (2006) A sensitive monoclonal antibodybased ELISA to quantifity Parietaria judaica major allergens, Par j1 and Par j2. Clin Exp Alllergy 36(1):87-93

Barber D, Carpizo J, Garcia-Rumbao MC, Polo F, Juan F (1990) Allergenic variability in olea pollen. Ann Allergy 64(1):43-46

Barral P, Batanero E, Palomares O, Quiralte J, Villalba M, Rodríguez R (2004) A major allergen from pollen defines a novel family of plant proteins and shows intra- and interspecies cross-reactivity. J Immunol 172(6):3644-3651

Barut E, Ipek A, Gulen H (2009) Distribution Of Olive (Olea europaea L.) Genotypes in the southern Marmara region of Turkey. Pak J Bot 41(3):1077-1080

Batanero E, Villalba M, Rodríguez R (1994) Glycosylation site of the major allergen from olive tree. Allergenic implications of the carbohydrate moiety. Mol Immunol 31(1):31-37

Bateman A, Coin L, Durbin R, Finn RD, Hollich V, Griffiths-Jones S, Khanna A, Marshall M, Moxon S, Sonnhammer ELL, Studholme DJ, Yeats C, Eddy SR (2004) The Pfam protein families database. Nucleic Acids Res 32:D138-D141 Database issue

Brito FF, Gimeno PM, Carnés J, Martín R, Fernández-Caldas E, Lara P, López-Fidalgo J, Guerra F (2011) Olea europaea pollen counts and aeroallergen levels predict clinical symptoms in patients allergic to olive pollen. Ann Allergy Asthma Immunol 106(2):146-152

Buters JTM, Thibaudon M, Smith M, Kennedy R, Rantio-Lehtimaki A, Albertini R, Reese G, Weber B, Galan C, Brandao R, Antunes CM, Jager S, Berger U, Celenk S, Grewling L, Jackowiak B, Sauliene I, Weichenmeier I, Pusch G, Sarioglu H, Ueffing M, Behrendt H, Prank M, Sofiev M, Cecchi L (2012) Release of bet v 1 from birch pollen from 5 European countries. Results from the HIALINE study. Atmos Environ 55:496-505

Buters J, Prank M, Sofiev M, Pusch G, Albertini R, Annesi-Maesano I, Antunes C, Behrendt H, Berger U, Brandao R, Celenk S, Galan C, Grewling Ł, Jackowiak B, Kennedy R, Rantio-Lehtimäki A, Reese G, Sauliene I, Smith M, Thibaudon M, Weber B, Cecchi L (2015) HIALINE working group. Variation of the group 5 grass pollen allergen content of airborne pollen in relation to geographic location and time in season. J Allergy Clin Immunol 136(1):87-95

Carnés Sánchez J, Iraola VM, Sastre J, Florido F, Boluda L, FernándezCaldas E (2002) Allergenicity and immunochemical characterization of six varieties of Olea europaea. Allergy 57(4):313-318

Castro AJ (2001) Aproximación a la función biológica del alérgeno mayoritario del polen del olivo (Ole e 1). Implicaciones clínicas y ambientales. Doctoral thesis. Granada (Spain): University of Granada

Castro AJ, Alché JD, Cuevas J, Romero PJ, Alché V, Rodríguez-García MI (2003) Pollen from different olive tree cultivars contains varying amounts of the major allergen Ole e 1. Int Arch Allergy Immunol 131(3):164-173

Conde-Hernández J, Conde-Hernández P, González-Quevedo MT, Conde-Alcañiz MA, Conde-Alcañiz EM, Crespo-Moreira P, Cabanillas-Platero M (2002) Antigenic and allergenic differences between 16 different cultivars of Olea europaea. Allergy 57(Suppl 71):60-65

D'Amato G (1998) Pollen allergy in the Mediterranean area. Rev Fr Allergol 38(1):160-162

D'Amato G, Liccardi G (1994) Pollen-related allergy in the European Mediterranean area. Clin Exp Allergy 24(3):210-219

D'Amato G, Cecchi L, Bonini S, Nunes C, Annesi-Maesano I, Behrendt H, Liccardi G, Popov T, van Cauwenberge P (2007a) Allergenic pollen and pollen allergy in Europe. Allergy. 62(9):976-990 
D'Amato G, Liccardi G, Frenguelli G (2007b) Thundestorm-asthma and pollen allergy. Allergy 62(1):11-16

Devalia JL, Rusznak C, Davies RJ (1998) Allergen/irritant interaction-its role in sensitization and allergic disease. Allergy 53:335-345

Diraman H (2010) Characterization by chemometry of the most important domestic and foreign olive cultivars from the National Olive Collection Orchard of Turkey. Grasas Aceites 61(4):341-351

Efe R, Soykan A, Curebal I, Sonmez S (2013) Olive and olive oil in Edremit Region. Edremit Municipality Cultural Publication No: 9, ISBN:978-605-62253-3-8

Erel R, Yermiyahu U, Van Opstal J, Ben Gal A, Schwartz A (2013) The importance of olive (Olea europaea L.) tree nutritional status on its productivity. Sci Hortic 159:8-18

Fernández-Caldas E, Carnés J, Iraola V, Casanovas M (2007) Comparison of the allergenicity and Ole e 1 content of 6 varieties of Olea europaea pollen collected during 5 consecutive years. Ann Allergy Asthma Immunol 98(5):464-470

Fernández-González D, González Parrado Z, Vega Maray AM, Valencia Barrera RM, Camazón Izquierdo B, De Nuntiis P, Mandrioli P (2010) Platanus pollen allergen, Pla a1: quantification in the atmosphere and influence on a sensitizing population. Clin Exp Allergy 40(11):1701-1708

Fernández-González D, Rodríguez-Rajo FJ, González-Parrado Z, Valencia-Barrera R, Jato V, Grau SM (2011) Differences in atmospheric emissions of Poaceae pollen and Lol p 1 allergen. Aerobiologia 27:301-309

Fernández-González M, González-Fernández E, Fernández-González D, Javier Rodríguez-Rajo F (2020) Secondary outcomes of the Ole e 1 proteins involved in pollen tube development: impact on allergies. Front Plant Sci 11:974

Fleming DM, Crombie DL (1987) Prevalence of asthma and hay fever in England and Wales. Br Med J (Clin Res Ed) 294(6567):279-283

Galán C, Antunes C, Brandao R, Torres C, Garcia-Mozo H, Caeiro E, Ferro R, Prank M, Sofiev M, Albertini R, Berger U, Cecchi L, Celenk S, Grewling L, Jackowiak B, Jäger S, Kennedy R, RantioLehtimäki A, Reese G, Sauliene I, Smith M, Thibaudon M, Weber B, Weichenmeier I, Pusch G, Buters JTM (2013) Airborne olive pollen counts are not representative of exposure to the major olive allergen Ole e 1. Allergy 68(6):809-812

Galán C, Smith M, Thibaudon M, Frenguelli G, Oteros JA, Gehrig R, Berger U, Clot B, Brandao R (2014) EAS QC working group. Pollen monitoring: minimum requirements and reproducibility of analysis. Aerobiologia 30:385-395

Geller-Bernstein C, Arad G, Keynan N, Lahoz C, Cardaba B, Waisel Y (1996) Hypersensitivity to pollen of Olea europaea in Israel. Allergy 51(5):356-359

Grote M, Valenta R, Reichelt R (2003) Abortive pollen germination: a mechanism of allergen release in birch, alder and hazel revealed by immunogold electronmicroscopy. J Allergy Clin Immunol 111: $1017-1023$

Hamman-Khalifa AM. (2005) Utilización de marcadores relacionados con la alergenicidady la biosíntesis de lípidos para la discriminación entre cultivares de olivo. Doctoral thesis. Granada (Spain): University of Granada

Hamman-Khalifa AM, Alché JD, Rodríguez-García MI (2003) Discriminación molecular en el polen de variedades españolas y marroquíes de olivo (Olea europaea L.). Polen 13:219-225

Hirst JM (1952) An automatic volumetric spore-trap. Ann Appl Biol 39: $257-265$

Jaradat ZW, Al Bzour A, Ababneh Q, Shdiefat S, Jaradat S, Al Domi H (2012) Identification of allergenic pollen grains in 36 olive (Olea europaea) cultivars grown in Jordan. Food Agric Immunol 23(3): 255-264

Kirmaz C, Yuksel H, Bayrak P, Yilmaz O (2005) Symptoms of the olive pollen allergy: do they really occur only in the pollination season? J Investig Allergol Clin Immunol 15(2):140-145
Knox RB (1993) Grass pollen, thunderstorms and asthma. Clin Exp Allergy 23:354-359

Lauzurica P, Gurbindo C, Maruri N, Galocha B, Diaz R, Gonzalez J, García R, Lahoz C (1988a) Olive (Olea europaea) pollen allergens-I. Immunochemical characterization by immunoblotting, CRIE and immunodetection by a monoclonal antibody. Mol Immunol 25(4):329-335

Lauzurica P, Maruri N, Galocha B, Gonzalez J, Diaz R, Palomino P, Hernandez D, García R, Lahoz C (1988b) Olive (Olea europaea) pollen allergens. II. Isolation and characterization of two major antigens. Mol Immunol 25(4):337-344

Lombardero M, Quirce S, Duffort O, Barber D, Carpizo J, Chamorro MJ, Lezaun A, Carreira J (1992) Monoclonal antibodies against Olea europaea major allergen: allergenic activity of affinity purified allergen and depleted extract and development of a radioimmunoassay for the quantitation of the allergen. J Allergy Clin Immunol 89(4): 884-894

Machia L, Caiaffa MF, D'Amato G, Tursi A (1991) Allergenic significance of Oleaceae pollen. In: D'Amato G, Spieksma FTM, Bonini S (eds) Allergenic pollen and pollinosis in Europe. Blackwell Scientific Publications, London, pp 87-93

Moreno-Grau S, Elvira-Rendueles B, Moreno J, García Sánchez A, Vergara N, Asturias JA, Arilla MC, Ibarrola I, Seoane-Camba JA, Suárez-Cervera M (2006) Correlation between Olea europaea and Parietaria judaica pollen counts and quantification of their major allergens ole e 1 and Par j 1-Par j 2. Ann Allergy Asthma Immunol 96(6):858-864

Moreno-Grau S, Aira MJ, Elvira-Rendueles B, Fernández-González M, Fernández-González D, García-Sánchez A, Martínez-García MJ, Moreno JM, Negral L, Vara A, Rodríguez-Rajo FJ (2016) Assessment of the Olea pollen and its major allergen Ole e 1 concentrations in the bioearosol of two biogeographical areas. Atmos Environ 145:264-271

Napoli A, Aiello D, Di Donna L, Sajjad A, Perri E, Sindona G (2006) Profiling of hydrophilic proteins from Olea europaea olive pollen by MALDI TOF mass spectrometry. Anal Chem 78(10):3434-3443

Obispo TM, Melero JA, Carpizo JA, Carreira J, Lombardero M (1993) The main allergen of Oleaeuropaea (Ole e I) is also present in other species of the Oleaceae family. Clin Exp Allergy 23(4):311-316

Peternel R, Srnec L, Culig J, Zaninović K, Mitić B, Vukusić I (2004) Atmospheric pollen season in Zagreb (Croatia) and its relationship with temperature and precipitation. Int J Biometeorol 48(4): 186-191

Plaza MP, Alcázar P, Galán C (2016) Correlation between airborne Olea europaea pollen concentrations and levels of the major allergen Ole e 1 in Córdoba, Spain, 2012-2014. Int J Biometeorol 60:1841-1847

Ribeiro H, Morales S, Salmerón C, Cruz A, Calado L, Rodríguez-García MI, Alché JD, Abreu I (2013) Analysis of the pollen allergen content of twelve olive cultivars grown in Portugal. Aerobiologia 29(4): 513-521

Rodríguez Rajo F, Jato V, González Parrado Z, Elvira-Rendueles B, Moreno-Grau S, Vega-Maray A, Fernández González D, Asturias JA, Suárez CM (2011) The combination of airborne pollen and allergen quantification to reliably assess the real pollinosis risk in different bioclimatic areas. Aerobiología 27(1):1-12

Rodríguez R, Villalba M, Batanero E, Gonzalez EM, Monsalve RI, Huecas S, Tejera ML, Ledesma A (2002) Allergenic diversity of the olive pollen. Allergy 57(Suppl 71):6-16

Rodríguez R, Villalba M, Batanero E, Palomares O, Quiralte J, Salamanca G, Sirvent S, Castro L, Prado N (2007) Olive pollen recombinant allergens: Value in diagnosis and immunotherapy. $\mathrm{J}$ Investig Allergol Clin Immunol 17(Suppl 1):4-10

Singer BD, Ziska LH, Frenz DA, Gebhard DE (2005) Increasing Amb a 1 content in common ragweed (Ambrosia artemisiifolia L.) as a function of rising atmospheric CO2. Funct. Plant Biol 32:667-670 
Soleimani A, Morales S, Jimenez-Lopez JC, Castro AJ, RodríguezGarcía MI, Alché JD (2013) Differential expression and sequence polymorphism of the olive pollen allergen Ole e 1 in two Iranian cultivars. Iran J Allergy Asthma Immunol 12(1):18-28

Solomon WR, Burge HA, Muilenberg ML (1983) Allergen carriage by atmospheric aerosol. I: ragweed pollen determinants in smaller micronic fractions. J Allergy Clin Immunol 72:443-447

Stratford S, Barne W, Hohorst DL, Sagert JG, Cotter R, Golubiewski A, Showalter AM, McCormick S, Bedinger P (2001) A leucine-rich repeat region is conserved in pollen extensin-like (Pex) proteins in monocots and dicots. Plant Mol Biol 46(1):43-56

Suárez-Cervera M, Seoane-Camba JA (2005) Biología celular del polen: origen y función de los alérgenos polínicos. In: Valero Santiago AL, Cadahía García A (eds) Polinosis II. Polen y Alergia. Empreso en España, Spain, pp 39-50

Suárez-Cervera M, Vega-Maray A, Castells T, Rodríguez-Rajo FJ, Asturias JA, Le Thomas A, Seoane-Cam JA (2008) An approach to the knowledge of pollen and allergen diversity through lipid transfer protein localization in taxonomically distant pollen grains. Grana 47:272-284

Turkeltaub PC, Gergen PJ (1991) Prevalence of upper and lower respiratory conditions in the U.S. population by social and environmental factors: data from the second National Health and Nutrition Examination Survey 1976 to 1980 (NHANES II). Ann Allergy 67(2 Pt 1):147-154

Vara A, Fernández-González M, Aira MJ, Rodríguez-Rajo FJ (2016a) Oleaceae cross-reactions as potential pollinosis cause in urban areas. Sci Total Environ 542:435-440
Vara A, Fernández-González M, Aira MJ, Rodríguez-Rajo FJ (2016b) Fraxinus pollen and allergen concentrations in Ourense (SouthWestern Europe). Environ Res 147:241-248

Villalba M, López-Otín C, Martín-Orozco E, Monsalve RI, Palomino P, Lahoz C, Rodríguez R (1990) Isolation of three allergenic fractions of the major allergen from Olea europaea pollen and $\mathrm{N}$-terminal amino acid sequence. Biochem Biophys Res Commun 172(2): $523-528$

Villalba M, Batanero E, López-Otín C, Sánchez LM, Monsalve RI, González de la Peña MA, Lahoz C, Rodríguez R (1993) Amino acid sequence of Ole e I, the major allergen from olive tree pollen (Olea europaea). Eur J Biochem 216(3):863-869

Waisel Y, Geller-Bernstein C (1996) Reliability of olive pollen extracts for skin prick tests. J Allergy Clin Immunol 98(3):715-716

Waisel Y, Geller-Bernstein C, Keynan N, Arad G (1996) Antigenicity of the pollen proteins of various cultivars of Olea europaea. Allergy 51(11):819-825

Wüthrich B (1989) Epidemiology of the allergic diseases: are they really on the increase? Int Arch Allergy Appl Immunol 90(1):3-10

Zohary D, Hopf M (1994) Olive: Olea europaea. Domestication of plants in the Old World. Clarendon Press, Oxford, pp 137-143

Zohary D, Spiegel-Roy P (1975) Beginnings of fruit growing in the old world. Science 187(4174):319-327

Publisher's note Springer Nature remains neutral with regard to jurisdictional claims in published maps and institutional affiliations. 